\title{
Similarity in Superstitions in Anatolian and Chinese Cultures
}

\author{
Güliz Ulu \\ Huazhong University of Science and Technology, Wuhan, China \\ Email: gulizulu@hust.edu.cn
}

Received 24 May 2016; accepted 27 June 2016; published 30 June 2016

Copyright (C) 2016 by author and Scientific Research Publishing Inc.

This work is licensed under the Creative Commons Attribution International License (CC BY). http://creativecommons.org/licenses/by/4.0/

(c) (i) Open Access

\begin{abstract}
This article aims at exploring similarity between Anatolian and Chinese prevalent superstitions, the reasons behind them and contributing to literature concerning superstitions. In this comparative study, marriage, birth, and death superstitions and their impacts on people's life have been investigated individually in Anatolian and Chinese cultures. As a result, the study concluded that superstitions have been a tradition, which is transferred from one generation to another. In both Anatolia and China, superstitions are mostly towards expelling evil spirits, avoiding bad things, and bringing good luck. In China, the most widespread superstitions are related to homophonic numbers whereas in Anatolia, wearing an evil eye talisman against evil eye is the most popular one. However, visiting a fortuneteller is very common superstition in both cultures and the most similar superstitions appear on birth customs. Results indicated that many superstitions originated from Shamanism, which is pre Islamic Asian origin Turkic religion. It is assumed that innumerable Anatolian and Chinese superstitions come from same ancient Shamanism and have survived until nowadays.
\end{abstract}

\section{Keywords}

Superstitions, Anatolian Superstitions, Chinese Superstitions, Marriage Superstitions, Birth Superstitions, Death Superstitions

"No one is so thoroughly superstitious as the godless man." Harriet Beecher Stowe

\section{Definition of Superstition}

"Superstition is a belief or way of behaving that is based on fear of the unknown and faith in magic or luck: a 
belief that certain events or things will bring good or bad luck"1. In another definition, superstition is "a widely held but irrational belief in supernatural influences, especially as leading to good or bad luck, or a practice based on such a belief"' . We can say that superstition is to believe in something that is not based on reality.

Since the first ages, people have believed in the supernatural, due to their fears and helplessness based on their old traditions. Superstitions are as old as humanity. Societies have their own superstitions because each society has different lifestyles and cultures. Therefore, superstition is considered naturally cultural inherent. Today, despite the progress of science and technology, superstitions still persist and live on. It can be even said that superstitions continue increasingly (Deeb \& Deeb, 2015).

Most of us believe in superstitions wholeheartedly because we are psychologically exposed to the negative effects of such beliefs. Even if we don't want to admit, the life of many people is under control of superstitions. Wang et al. (2012) indicate that superstitions show positive impact on decision effectiveness and satisfaction. Furthermore, when superstitious managers face an important, uncertain, and urgent strategic decision, they are more likely to use superstitions.

\section{Prevalent Superstitions in Chinese and Anatolian Cultures}

Most prevalent Chinese superstitions are based on Chinese homophony. Chinese people use polytone syllables for the construction of words. Many unrelated concepts are expressed in the same syllable in Chinese language. Most of Chinese superstitions arise from these unrelated syllable as if they were related to each other.

In China, one of the most important homophony superstitions is "dao" syllable. This syllable means "arrive (到)” and “upside down (倒)”. Therefore, in Chinese New Year and wedding, people believe that hanging 福 (fú = luck) character upside down, brings good luck.

For a similar reason, Chinese believe that the bats bring good luck. Biān (蝙蝠 = bat) includes the fú (福) syllable. This homophonic relation regards bats as the most important theme of Chinese folk art. Most houses have bats symbol made from paper for good luck.

Yet, not all homophonic syllables refer to good luck. Number four, which is pronounced s1 (四), is considered inauspicious because it is homophonic with s1 (死 $=$ death) character and so, number four is not used in numbering hotels` rooms, houses and so forth (Shum et al., 2014; Ulu, 2012). On the contrary, for example number eight (八) is the furthermost looked-for number in China that people pay considerable money to own a telephone number or a car plate with number eight, simply because this number symbolizes wealth and good luck. There is ample anecdotal evidence regarding the importance of "lucky numbers" in Asian real estate markets, even real estate markets in non-Asian countries with a high percentage of Asian immigrants (Shum et al., 2014). In Addition to this, when the Beijing Summer Olympics opened at 08:08:08 pm on the 8th day of the 8th month of 2008, it was shown to the world that the Chinese take the auspiciousness of the number "8" seriously. (Ulu, 2012; Fortin et al., 2013).

Although the origin of many superstitions had been forgotten long time ago, they still exist in our daily life as a habit or as a tradition. From ancient times, Chinese superstitions can not be distinguished from traditions and cultural beliefs even if laws are imposed to ban them (Deeb \& Deeb, 2015).

Like Chinese culture, Anatolian culture is considered rich in terms of superstitious beliefs. Amongst the Anatolian superstitions, one of the most well-known and common belief is to hang on or wear a blue bead against the evil eye which is called "nazar" (to be coveted) in Turkish. Underneath of the origin of this belief there is reflection in the human eye. When ancient people see reflection of their faces inside of others' eye before them, they assume that they are in danger and their soul is confined within the eyes of others. Over the time, this belief has been altered to the form that the eyes with a stare full of jealousy and envy would eventually cause death and sickness. Therefore, many people believe that hanging or wearing a bluish glass bead in the form of an eye (nazar boncuğu) would reflect these gazes back and save the person at stake.

The belief "Nazar" also exists among Central Asian Turks, especially in ancient Shamanism ${ }^{3}$ (Ulu, 2012). In Anatolia, "kurşun dökme" superstition is believed to repel evil eye and practiced by completely melting the lead in a ladle on fire. Following this, the lead in the liquid phase is poured into a bowl of water, over the head of the person exposed to evil eye who is covered with a big piece of cloth. By means of pouring the lead, it is believed that all negative things, enemies, and "nazar" will be repelled. The origin of this superstition is Shamanism

\footnotetext{
${ }^{1}$ www.merriam-webster.com/dictionary/superstition.

${ }^{2}$ www.oxforddictionaries.com/definition/english/superstition.

${ }^{3}$ Shamanism is a practice that involves a practitioner reaching altered states of consciousness in order to perceive and interact with a spirit world and channel these transcendental energies into this world. (https://en.wikipedia.org/wiki/Shamanism).
} 
which is named as "Kut ${ }^{4}$ pouring" (İnan, 2006). Owing to kut pouring, Shamans tries to bring their kut which is stolen by evil spirits (Algül, 2007). All Anatolian nations such as Babylonians, Egyptians, Sumerians and Akads from the ancient and the recent times have always believed in "nazar" (Eyüboğlu, 2007). Moreover, the presence of "nazar" is also mentioned in Islam religion.

Another common superstition in Anatolia is "knocking on wood" belief. When people talk or hear about something scary, they would immediately say "knock on wood" believing that knocking on wood would save people from that bad incident and that the similar trouble could be prevented to happen to them. Also, when some water is poured behind people to set off on a journey, it is believed that they can reach their destination and come back home as runny as water. It is believed that the origin of superstitions comes from Shamanism according to some sources although not yet certain.

Another common and widespread superstition in Chinese and Anatolian cultures is visiting fortunetellers to foretell the future. In China, fortunetellers are in everywhere, on streets, bus stations and so on due to people's heavy demand. As for Anatolia, coffee fortunetelling through Turkish coffee cup is very popular among Turkish people. Furthermore, customarily people run across fortunetellers in coffee shops where they can foresee their future. Fortunetelling dates back to ancient times of Turkish culture (Gömeç, 1998) likewise Chinese culture, is also prevailing in Shamanism (Abdurahim, 2006). Although Turkish people's religion turned from Shamanism to Islam centuries ago, there are still numerous customs and traditions inherited from Shamanism (Algül, 2007).

In the chapters below, superstitions have been compared on the subject of marriage, birth, and death in Anatolian and Chinese cultures.

\section{Superstitions Regarding Marriage}

Investigating marriage traditions in China, we find out several similarities in Anatolian and Chinese cultures. For instance, it is common among many cultures that wearing the wedding dress before the ceremony would bring a bad luck. Chinese brides do not wear their wedding dresses before the ceremony assuming that if the dress is worn more than once, the marriage would be more than only one time as well. The main cause behind this belief either in Anatolia or in many other countries was to keep the wedding dress neat and clean until the day of the ceremony and also it is an expensive gown and it is not possible to replace it in case of an accidental damage to it. Consequently, it may cause a delay in the predetermined date of the wedding.

In Chinese traditions as well as Anatolian, sprinkling rice over bride and groom is believed to make them rich ever after and brings fortune in abundance to their marriage. Even though this custom is replaced by sprinkling confetti over bride and groom in today's metropolitan cities, this tradition still prevails in villages and towns. Furthermore, in the Central Anatolia, when a bride comes to the groom's home after the wedding ceremony, she breaks an earthenware jug, which is filled with money, candies, wheat etc., by hitting the ground, in the door of her new house. It is believed that this tradition, which is called "testi kırma" in Turkish culture, will bring wealth and plentifulness and (if there is) bad habits of this bride are shattered together with this pottery. In the Kizılcahamam territory in Anatolia, it is believed that if a bride breaks a spoon by stepping on it while she is passing through the door of her new house would bring plentitude to the couple's home (Elçin, 1965). Likewise, in China people believe that breaking some materials during the wedding ceremony would bring good luck to this newly married couple (Ulu, 2012).

While the bride is supposed to wear white on her wedding day, it is not so in Chinese culture, red color can be worn on the wedding day for a lucky marriage (Deeb \& Deeb, 2015). However, in many other countries and in Anatolia, white color is preferred for the color of the wedding dress as symbol of purity and innocence. Besides, in Anatolia, a red kerchief put on a bride's head as well as in China. Red color symbolizes virginity, purity, honor, and leaving the father's home. This tradition has survived since ancient Turks to the present time. Following Turks' conversion to Islam, this tradition passed on to Arab societies.

Superstitions regarding marriage can exhibit variation among cultures. However, there are similarities among each tradition and culture as well. Nevertheless, foundations beneath the marriage superstitious beliefs are almost the same.

\section{Superstitions Regarding Birth}

The similarities regarding birth beliefs and traditions between the Anatolian and the Chinese cultures can be ${ }^{4}$ Kut means fortune, luck in Shamanist culture (Algül, 2007). 
observed more frequently compared to the other highlighted conditions.

Like a rough times of the pregnancy period, dietary habits are also important and can totally change. Craving some foods which can be seen frequently during the pregnancy period, is an important issue in Anatolia as it is in China. It is thought that the mother must have a taste of whatever she craves for. In Anatolia, people attribute some meaning to this situation. For instance, if a pregnant craves for sour foods, people believe that she will have a baby girl and if she craves for sweet foods, she will have a baby boy. If she does not eat the food she craves for, it is believed that there will be a spot on the baby's body. In China, people beleive that the pregnant woman must eat whatever she craves, even harmfull food, othervise the baby will have the slabbery mouth.

Chinese pregnant women avoid to eat very hot or cold food which cause the fair of miscarriage. In China, dietary of pragnant woman is based on "Ying-yang"5 theory which supports the balance of opposite powers. If Pregnancy is considered a hot period, pregnant woman is suggested to eat cold food, in the same way, the period after bearing a child is considered as cold period so woman suppose to eat hot food (Brathwaite, 2004).

In both China and Anatolia, an expectant mother is not allowed to perform heavy duty or to carry heavy load because this may cause miscarriage. In China, a pregnant woman sleeps while all lights are left on so as to prevent the dark days in baby's future. The same tradition exists in Anatolia but its cause is unknown (Ulu, 2012).

In Turkish culture, the most common postnatal customs are consisted of beliefs related to funiculus, puerperality, "albasma", and "nazar" (Güngör, 2007: p. 5; Maden, 1991: p. 357). In China, traditions about birth are almost same with Anatolia. In Anatolia and China, a baby is not named before s/he is born. Diversely in China, to accept a baby into a family, people will wait for a month (manyue) ${ }^{7}$ and then give name to her/him. In Anatolia, naming a baby during the first week is preferred. Based on Islamic faith, the name is given through a religious ritual in which adhan ${ }^{8}$ is recited in the baby's ear and the name is repeated three times as well.

Since in many cultures, funiculus is considered as part of a baby so its fate has been related to the baby's fate. Therefore, funiculus rituals are important in Anatolian culture; the funiculus is thrown into running water or wrapped with a clean cloth and buried in a place that is related to her/his expected job in future. For example, the funiculus is buried into a school garden if parents hope the baby to be a teacher or in a hospital garden if they want the baby to be doctor in the future and so on. As far as it is possible, funiculus is not left in a place where there is probability that it can be eaten by animals (Bahar, 1985: p. 246; Hotun, 1990: p. 18; Türkdoğan, 1982: p. 590).

Chinese believed that a newborn baby is being protected against ghosts if the mother does not leave the baby alone during her puerperium. Furthermore, parents don't show their baby to strangers apart from familiy members, before her/his first month (Bratwaite, 2004). Additionally, they prefer red color on baby clothes to get rid of evil spirits. In Anatolia, it is believed that a puerperant woman's grave is open for 40 days and thus, the mother and her baby are strictly not allowed to leave home for 40 days and the baby must not be left alone (İsmail, 1983). This ritual is colloquially called "kırkı çıma" (completing forty-day grace period). Origin of this custom can be based on logical reasons, for example, the process of becoming a mother and the process of adaptation to the changes in her body, a puerperant woman can sink deeper into depression. Sometimes such conditions can cause suicidality, hence a puerperant woman should neither leave her home nor stay alone for 40 days. Additionally, it is believed that in case the baby's nails are cut during this 40-day grace period, it will have a shameless-larcener character.

In China, to protect the fetus from evil spirits, some pregnant women would keep a knife under the bed (Ulu, 2012). This tradition can be observed in Anatolia following a baby's birth. It is believed that if puerperal mother keeps a needle or knife under the baby's pillow or the cradle, the "Albasti" does not occur (Kalafat, 2010). "Albastl" is considered a serious danger for both the baby and the mother during the 40-day puerperium (Biçer, 1991; Güngör \& Köylü, 2014). Based on this belief, it is thought that the mother and her baby in the puerperium

\footnotetext{
${ }^{5}$ In Chinese philosophy, yin and yang (also yin-yang or yin yang, 陰陽 yinnyáng “dark—bright”) describes how opposite or contrary forces are actually complementary, interconnected, and interdependent in the natural world, and how they give rise to each other as they interrelate to one another.(https://en.wikipedia.org/wiki/Yin_and_yang).

${ }^{6}$ Albastı or Albasma is a common belief that evil spirit in all Turkic tribes.

${ }^{7}$ 满月 mănyuè, full moon, is when a baby turns 30 days old. In China, it’s tradition to cut a baby's hair and baby shower for manyue celebration.

${ }^{8}$ Adhan (أَذَان in Arabic) means the call to prayer in Islam religion. The Adhan is recited by a “muezzin”, a person who has the responsibility to call people to offer prayers for ALLAH.. Muazzin has to recite the Adhan five times a day; these prayer times are known as Fajar, Zuhr, Asar, Magrib and Isha. Adhan holds a strong significance in the lives of Muslims. It is the first thing recited in the ears of a newborn baby; and often the first thing that is recited in times of grave sorrow and sheer happiness too. Adhan is actually a recitation to mention Allah's greatness.
} 
are under threat of "albastı" which is believed to eat baby’s lungs. Somehow a needle or a knife is stabbed into "albastı" is believed that it can not recover itself again and it will serve to that family forever. Therefore, some metals such as needle and knife should be placed underneath the baby's cradle. Moreover, it is believed that wearing a red ribbon around a puerperant woman's head also would protect her and the baby. The belief regarding Albastı has been observed among Turks since very ancient times and still continues in Anatolia. This belief is also significant to Turkic countries except Anatolia region and dates to pre-Islamic faith system of Turks, Shamanism (Algül, 2007). There are several and similar prevention methods and ways mentioned in the literature in Kyrgyz, Kazakh, Uzbek, Kazan Tatars and Anatolian Turk societies to protect mother after birth. Existence of such a similar belief in both Chinese and Anatolian cultures makes us think that there is Shamanism on the background of these two cultures (Ulu, 2012).

In China, the first bath of a baby is taken on the third day after birth with a celebration. In Anatolia, a newborn baby takes first bath on the third day likewise, for this event, family elders are invited for a special dinner. Unlike the Chinese custom, the baby is bathed with salty water so that s/he does not smell bad and to prevent heat rashes which may arise. The baby takes another bath when s/he turns 40 days. Moreover, 40 different stones collected from 40 different places are put in the bathing water believing that this would bring good fortune to the baby. After soaping the baby for the last time, the baby is rinsed with 40 bowls of water. This rinsing process is called "kırk çıkarma" (completing forty-day grace period) or "kırklanma". Then, the baby is taken to a close neighbor for "Kırk uçurma". If this baby does not encounter any negative incident until his/her " $k ı r k$ çıkarma” (completing forty day grace period), it is believed that s/he will not face bad things again in the future. On the other hand, "Kırk uçurma" is a visit of another house all together with family elders by dressing the baby in new clothes. It is better if the house is large and located on a higher position with perpetual fresh air. Furthermore, it is desirable that if the residents of this house are healthy, happy, in peace, rich and have significant status in the society, believing this would bring good luck to the baby's life.

\section{Superstitions Regarding Death}

Although Chinese and Anatolian funeral customs are different from each other in some aspects, both are significantly important in both cultures. In Anatolia, funerals abide by Islamic rules, whereas, Chinese funerals and burial traditions are arranged based on the age of the decedent, cause of death, their status in the society, and their marital status. Although family of the decedent may not be wealthy, the funeral ceremony is supposed to be carried out with borrowed money (Ulu, 2012).

Funeral rituals are a significant custom in Chinese culture. Ceremonies are paid great consideration to let the soul of the decedent find peace. It is believed that unless a great funeral is arranged for the passed away person, his/her soul would return and disturb the family. Playing some music instruments, such as trumpet and bell, in front of the decedent's home is quite common superstition believing that loud noise would expel bad spirits (Ulu, 2012).

In Chinese culture, if the decedent dies at home, the coffin is brought home and if s/he dies outside the house, the coffin is put to the garden of the house. The decedent's relatives put foods which were decedent's favorite, nearby the coffin (Emily \& Emily, 1973). Moreover, picture of decedent, some gifts, flowers also place near the coffin. Some fake money, house, furniture which are all made from paper, are being burnt during the funeral believing that the decedent will need them after life. A donation box is arranged for people, who come to express condolences, to offer money to relatives of decedent in order to show their respect to decedent and help for expenses of funeral (Emily \& Emily, 1973). After that, a funeral procession to the graveyard or crematorium is held. A hired band resembling a marching band typically leads the procession. The band plays loud music to frighten spirits and ghosts also in graveyard.

As for Anatolian funeral rituals, bathing, enshrouding and prayer held for him/her are an obligation according to Islam, before the decedent is buried. In general, the decedent should be buried immediately after people perform the next prayer time of the day. Mostly, if a person dies later than the afternoon prayer time, it is kept waiting overnight. There are several reasons for burying dead corpse and rejoining with earth as soon as possible for preventing putrefaction, swelling and so on (Örnek, 1971: p. 48).

In Anatolia, if the person dies at home, bathing process takes place in that person's home, dooryard, or somewhere around his/her home. For the person who died in a hospital, bathing process is carried on within bathing cubicles at the hospital. If the person is female, a knowhow woman baths the corpse; if decedent is male, a knowhow man baths the dead body. During bathing, an ablution process is performed so that the person can 
journey everlasting life as a clean one. After bathing, enshrouding is the next procedure. Since white color represents pureness, the shroud must be from white color cloth. Soon after the enshrouding, funeral prayer is performed by Muslims. Then, the body is taken to the graveyard for burial. Children are not allowed to join the burial, whereas women are permitted to join the burial just in few places (Örnek, 1971: p. 58).

Completing the burial stage and sealing the grave, prayers are said upon the decedent's grave and some water is poured over the grave so that soil on the grave can be compressed. Pouring water ritual is repeated during the further visits in the future. The custom of pouring water over the grave is inherited from the times of Turks when they were believing in Shamanism. In this ancient period, Shamans used to believe that dead people drink water in some special days. Thus, a bowl or a cup full of water used to be left next to the grave or hanged to the tombstone.

In Anatolia, the major and irreplaceable characteristic of funerals is offering food to the people who join the funeral, believing that, this ritual will relieve the soul of the decedent and make him/her rest in peace. Ancient Turks considered offering food for their ancestors a significant duty; they used to arrange food offering ceremony which was called "yoğ” (Güngör, 2007: p. 4; Günay \& Güngör, 1997). In the pre islamic ages, food was presented directly to the decedent by leaving or pouring the meal onto their grave. After embracing Islam, this custom was implemented in a different way by offering food and halva, mostly, to poor people for the soul of the person passed away (İltar, 2003).

Offering food is a common funeral aspect everywhere in Anatolia. Varieties of food offered during the funeral differ from one region to another. Offering food is held in different days according to region such as the day of funeral, the third, seventh, fortieth and fifty second day after the passing away (Örnek, 1971: p. 91).

People in Anatolia usually prefer wearing black or dark colored clothes for funerals however, in China, people wear clothes in different colors based on their degree of affinity with the decedent. In Anatolia, mourning varies between three days and seven years. In China, the mourning band is worn for the duration of the mourning period that can last up to 100 days. Mourners also wear somber clothes. Bright and colorful clothes are avoided during the mourning period.

As to Anatolian culture, the family of the decedent send away his/her clothes from home as soon as possible by donating them to poor people due to the fear of his/her return and to wish letting his/her memory survive.

Although funerals in Anatolia are carried out according to the Islamic faith, there are still pre-Islamic Turkish customs are included in today's applications (Algül, 2007).

The number forty, as mentioned several times earlier, can be encountered frequently in Turkish culture and legends. Especially, "kırk uçurma" and "kırkı çıkma" (completing forty days) in the birth customs and praying for forty days after death of someone is based on Shamanism from the ancient Turks. In Shamanism, the soul leaves the dead body after forty days (Güvenç, 2009). Furthermore, number forty is sacred number in Islam, Christianity and Judaism religions as well.

Some numbers posses a meaning more than just their numerical value. For instance, in Turkish language, number forty means "a lot" alongside its numerical value. There are several phrases which contain number forty inside such as "Ali Baba and the forty thieves", "the forty days and forty nights wedding", "a cup of coffee represents the sake of a forty years friendship", "a forty year long friendship", "once in every forty year" etc. In all of these phrases, forty means plentifulness (Güvenç, 2009). The phrase of "kırkbir kere maşallah (41 times praise be)" means one more than plentiful.

In Chinese, the number ten-thousand has similar meaning with the number forty in Turkish. The number ten-thousand represents plentifulness. For instance, “The Great Wall” in Chinese is called “万里长城 Wàn lǐ cháng chéng” which means "ten thousand mile long wall”. The phrase of "ten thousand” in here refers plentifulness; thus, it represents the meaning of "very long wall" (William, 2007).

\section{The General Situation of Superstitions in China and Anatolia}

After interviewing several people from both China and Anatolia about the effects of Chinese superstitions on their daily life, people from various ages indicated that superstitions are indistinguishable parts of the society and affect daily life because people practice what they learn from their family elders. Interviewed people stated that they embrace superstitions just to take measure because they fear that something bad may happen to them in the future. The majority of interviewees in China specified that they prefer to believe in superstitions to certain

\footnotetext{
${ }^{9}$ Traditional Chinese mile; 里 lǐ 500 meters or half kilometer.
} 
extend furthermore if they foresee that something is not lucky for them, they would keep away from it and vice versa. However, elder Chinese thought that young generations were widely affected from the western culture and youth prefers western culture to own culture. Moreover, they are worrying about losing Chinese values and traditions as well. In Anatolia, when people were asked about superstitions, some of them expressed that they were just a force of habit, whereas some people indicated that they can not distinguish superstitions and customs. Some interviewees in Anatolia and China had different opinion as to superstitions stating that due to the young generations' belief in science and technology, they know what is good or bad for them, and they do not rely upon superstitions. Nowadays, in both Anatolian and Chinese cultures, people still visit fortunetellers to foresee the best time to have a baby or to get married, believe in lucky and unlucky numbers, wear protective talismans or hang them on their homes and cars againts evil eye and evil spirits.

\section{Conclusion}

In Anatolian and Chinese cultures, the prevalent superstitions, regarding marriage, birth and death, are briefly discussed due to rarity of sources. After reviewing the relevant literature and observing Chinese and Anatolian social life, the results pointed out that many superstitions have been a lifestyle, which are indistinctive from customs and passed on from one generation to another.

It was determined that the most widespread superstition in Chinese culture is homophonic numbers. For instance, superstition about number four is the result of its phonetic resemblance to the word "death". This belief took the society under its effect so much that in some building elevators there is no number four used. As to Anatolian culture, the most prevalent superstition is wearing evil eye talisman (nazar boncuğu) against evil eye (nazar). However, visiting a fortuneteller is very common superstition in both Anatolia and Chinese cultures.

Having researched superstitions about marriage, birth, and death aspects, the results concluded that Anatolian and Chinese superstitions share similarities. The most similar superstitions in between Chinese and Anatolian cultures are found in birth customs like protecting the baby and the mother from evil spirits. In China and Anatolia, pregnant women and fetuses or puerperant mothers and newborns are tried to protect from evil spirits by using red color cloths and metal objects such as knife and needle. In both cultures, it is not preferred to leave baby alone to protect from evil spirits during postpartum period. The Chinese evil spirits are known in Anatolian culture as "Albasti".

Regarding marriage superstitions, it is believed that breaking some materials, sprinkling rice over newlywed couple would bring good luck to them; these superstitious beliefs are widespread in Chinese and Anatolian cultures.

As to funeral rituals, funerals and mourning are very important in both cultures. Even though Anatolian people follow Islamic funeral rites and ceremonies, they still practice some rituals holdover Shamanism.

Although it has been ten centuries since Turks embraced Islam, many cultural elements in contemporary life bear the trace of the pre Islamic Asian origin Turkic cultures and religions. Most importantly, Shamanism, which arises from Asia in ancient time, underlies the numerous superstitions of people's daily life. While origin of Turks were migrating from Central Asia to Anatolia, they brought their customs and superstitious beliefs with them and today, some similar customs and superstitions are still in existence in China. It is assumed that Turkic and Chinese cultures had been involved in an interaction in their ancient times.

\section{References}

Abdurahim, R. (2006). Uyğurlarda Şamanizm, Milletler Neşriyatı, Pekin s. 3. In A. Öger, \& T. Gönel (Eds.), (2011), The Shamans among the Uyghur Turks and the Shamans’ Treatment Methods. Turkish Studies International Periodical for the Languages, Literature and History of Turkish or Turkic Volume 6/4 Fall 2011.

Algül, N. (2007). Türk Kültüründe Şamanist İletiler. Marmara İletişim Dergisi, Sayı: 12, Ocak 2007, İstanbul.

Bahar, Z., \& Bayık, A. (1985). Doğanlar Mahallesinde Annelerin Çocuk Bakımına İlişkin Geleneksel Davranışlarının İncelenmesi, In I. Ulusal Hemşirelik Kongresi (pp. 241-251). İzmir: Ege Üniversitesi Matbaas1.

Biçer, M. (1991). Eskişehir İlinde Doğumla İlgili Adet ve İnançlar (p. 11). Ankara: Türk Halk Kültüründen Derlemeler.

Bratwaite, A., \& Williams, C. (2004). Childbirth Experiences of Professional Chinese Canadian Women. JOGNN, 33, 748755. http://dx.doi.org/10.1177/0884217504270671

Deeb, A., \& Deeb, E. (2015). Between Two Cultures-Finding Meaning in Amy Tan’s Use of Superstitions. European Journal of English Language and Literature Studies, 3, 76-108. 
Elçin, Ş. (1965). Kızılcahamam Folkloru, TFA, 9.cilt, Ekim, No.195, İstanbul. In A. Başçetinçelik (Ed.), (2009). Adana Halk Kültüründe Doğum-Evlenme-Ölüm. Altın Koza Yayınları: 50, Ulusoy Ofset, Aralık s.3876-3878, Adana.

Emily, M., \& Emily, M. A. (1973) The Cult of the Dead in a Chinese Village. Redwood City, CA: Stanford University Press Eyüboğlu, İ. Z. (2007). Anadolu İnançları. İstanbul: Derin Yayınları.

Fortin, N. M., Hill, A. J., \& Huang, J. (2013). Superstition in the Housing Market. Vancouver School of Economics, Vancouver: University of British Columbia.

Gömeç, S. (1998). Shamanism and Old Turkish Religion. Pamukkale Üniversitesi Eğitim Fakültesi Dergisi. Sayı:4.

Günay, Ü., \& Güngör, H. (1997). Türkler'in Dinî Tarihi. Ankara: Ocak Yayınları.

Güngör, H. (2007). Geleneksel Türk Dininden Anadolu'ya Taşınanlar (pp. 1-5). Ankara: Hacettepe Üniversitesi Türkiyat Araştırmaları Enstitüsü.

Güngör, H., \& Köylü, B. (2014). Türk Halk İnanışları Ders Notları. Kayseri: Erciyes Üniversitesi İlahiyat Fakültesi.

Güvenç, A. Ö. (2009). A Study on The Use in the Products of the Folk Literature of the Number of Forty. A.Ü. Türkiyat Araştırmaları Enstitüsü Dergisi Sayı 41 Erzurum.

Hotun, N. (1990). İstanbul İli Halkalı Bölgesinde Deki Kadınların Gebelik Ve Doğuma İlişkin Geleneksel İnanç ve Uygulamaları. Yayınlanmamış yüksek lisans tezi. İstanbul Üniversitesi Sağlık Bilimleri Enstitüsü.

İltar, G. (2003). Eski Türklerde Mezar Kültü ve Günümüze Yansımaları. Türk Kültürü ve Hacı Bektaşi Veli Araştırma Dergisi, Güz 2003, S. 27, Ankara, 7-16.

İnan, A. (1976). Eski Türk Dini Tarihi. İstanbul: Milli Eğitim Basımevi.

İnan, A. (2006). Tarihte ve Bugün Şamanizm Materyaller ve Araştırmalar. Ankara: Türk Tarih Kurumu.

İsmail, Ö. (1983). Yeniken Köyünde Çocuklara Ad Koyma (p. 174). Ankara: Türk Folklor Araştırmaları.

Kalafat, Y. (2010). Doğu Anadolu'da Eski Türk İnançlarının İzleri (p. 80). Ankara: Berikan Yayınevi.

Maden, A. (1991). Türklerde Doğumla İlgili Adet ve İnanmalar. Türk Aile Ansiklopedisi. Ankara: Başbakanlık Aile Araştırma Kurumu Yayını, 1, 357.

Örnek, S. V. (1971). Anadolu Folklorunda Ölüm. Ankara: Üniversitesi Basımevi.

Shum, M., Sun, W., \& Ye, G. (2014). Superstition and "Lucky” Apartments: Evidence from Transaction-Level Data. Journal of Comparative Economics, 42, 109-117. http://dx.doi.org/10.1016/j.jce.2013.10.001

Türkdoğan, O. (1982). Doğu Anadolu'da Ana-Çocuk Bakımı ile İlgili Kültür Kalıpları. II. Milletlerarası Türk Folklor Bildirileri. Ankara: Kültür ve Turizm Bakanlığı.

Ulu, G. (2012). The Effects of Superstitions on Chinese Community Life. Published Master's Degree Thesis, Ankara: Ankara University.

Wang, S., Chen, D., \& Dong, J. (2012). Superstition in Strategic Decision Making: A Two-Level Study. In Stanford University Workshop, 20-21 January, California: Stanford University.

William, L. (2007). The Great Wall Revisited: From the Jade Gate to Old Dragon's Head (p. 21). Beijing: Wuzhou Publishing. https://en.wikipedia.org/wiki/Great Wall of China

\section{Submit or recommend next manuscript to SCIRP and we will provide best service for you:}

Accepting pre-submission inquiries through Email, Facebook, Linkedin, Twitter, etc

A wide selection of journals (inclusive of 9 subjects, more than 200 journals)

Providing a 24-hour high-quality service

User-friendly online submission system

Fair and swift peer-review system

Efficient typesetting and proofreading procedure

Display of the result of downloads and visits, as well as the number of cited articles

Maximum dissemination of your research work

Submit your manuscript at: http://papersubmission.scirp.org/ 